\section{Is naming brands in English worth doing? Effects of foreignness and country of origin on brand equity}

\author{
Rafael Barreiros Porto ${ }^{1, \dagger}$ \\ ${ }^{1}$ Universidade de Brasilia, Brasilia, DF, Brazil \\ Talyta da Silva Soyer ${ }^{2, \Omega}$ \\ ${ }^{2}$ Universidade de Brasilia, Brasília, DF, Brazil
}

\begin{abstract}
The effect of the brand identity strategies, foreignness and country of origin, on brand equity raises questions about the effectiveness of the names given by entrepreneurs to commercial establishments. This study investigates the influence of foreignness and country of origin on consumer-based brand equity. We conduct a $2 \times 2$ between-subjects experiment with 280 participants, using brand foreignness and country of origin as manipulated variables and brand equity as the dependent variable. The results show a positive and direct effect of foreignness on brand equity indicators, associated image and willingness to pay a premium price. Country of origin moderated the relationship between foreignness and brand equity, showing that a brand with foreignness increases exclusivity without any identification of the country of origin and that a brand without foreignness increases the same indicator when the country of origin is present. This research may help in building and managing new product, service, and retail brands.
\end{abstract}

Keywords: English foreignness, Brand equity, Country of origin, Branding, Experiment.

\section{INTRODUCTION}

Brazil is considered a country with a highly diversified cultural identity. Since its formation, it has received influences from various countries as a result of political, commercial, and cultural relationships (GONÇALVES, 2017). Due to the commercial strength of English-speaking countries, the use of terms in English has become recurrent in the day-to-day life of Brazilians, especially those originating from the United States of America (MORAIS; MARRA, 2011).

Currently, English holds the status of globally hegemonic language (PENNYCOOK, 2017), with it being used as the language of commercial relations and scientific publications, such that it is the one that lends most terms to other languages. The presence of English foreignness in the commercial environment is thus notable. It can be seen all around, in posters and billboards, in store names, restaurant menus, $t$-shirt slogans, and even in street graffiti. In many organizations, the influence of foreignness is even perceived in the building of regional brands, making English words very common for the Brazilian consumer (LEITE et al., 2012; SCHMELTZ; KJELDSEN, 2016).
Corresponding author:

† Universidade de Brasília, Brasília, DF, Brazil. E-mail: rafaelporto@unb.br

${ }^{\Omega}$ Universidade de Brasilia, Brasília, DF, Brazil.

E-mail: talyta.soyer@hotmail.com

Received: $12 / 18 / 2017$.

Revised: 03/12/2018.

Accepted: 03/15/2018.

Published Online: 07/25/2018.

DOI: http://dx.doi.org/10.15728/bbr.2018.15.6.6 
At the same time, the Brazilian industrialization process via the substitution of imported products (CORONEL; DE AZEVEDO; CAMPOS, 2014) has led to Brazilians seeing brands of products from foreign countries, together with Brazilian ones in innumerous product categories. This, among other things, enables the existence of brands originating from a variety of countries competing for selection with domestic brands. The country of origin has thus become a decision-making criterion for consumers, signaling quality and price depending on which country the product originates from.

Therefore, English foreignness and disclosing the country of origin of a brand have become brand identity strategies that can alter consumers' choices in product and service categories (HILLENBRAND et al., 2013; BRODIE; BENSON-REA, 2016). The speed with which entrepreneurs adopt these foreign identities of national brands, and disclosures regarding the country of origin are carried out, it creates the impression that English foreignness is a successful branding strategy in the consumer market (PRADO, 2015). However, this effectiveness has not yet been proven by scientific tests. Part of the absence of proof is due to the lack of clarity regarding consumers' reactions caused by brands with English foreignness and the disclosure of their countries of origin.

The findings from the area of consumer-based brand equity (AAKER, 1996) present a possible path that would make demonstrating these reactions viable. A brand with a name in English may be associated with a more positive image and consumers being willing to pay more for this. In addition, a message that values the country of origin as being the United States of America may interfere with how much the consumer judges there to be affinity between the foreignness of the brand and its respective equity.

We can add some methodological difficulties to this. The brand equity contains some different indicators - those of brand knowledge, associated image, perceived quality, exclusivity, loyalty, and willingness to pay a premium price (PORTO, 2018) - which may lead to it not being clear which of the indicators is creating the effect. Moreover, in market practices it would be difficult to test the effectiveness of the English name of a foreign brand on its consumer-based brand equity, because this would require an alternative brand with the same name, but in Portuguese. Thus, a test in a more controlled environment and with fictitious brands could solve this problem, eliminating any pre-existing judgments and enabling effectiveness comparisons.

Thus, the general aim of this study is to investigate the influence of English foreignness and country of origin on consumer-based brand equity. We subdivide this brand equity into each one of its indicators. The knowledge from this study could help managers when creating the identity of a product, service, or retail brand, specifically when they need to elaborate a brand naming strategy and decide whether or not it should be associated with the country of origin. In addition, understanding the influence of the variables tested in each dimension of brand equity contributes to decisions regarding differentiation in the company's market, with managers being able to discover whether the brand has become more exclusive, whether its image has improved, and even whether there is the possibility of pricing it at a higher level.

After this introduction, the article presents a theoretical review arguing that foreignness and country of origin are types of branding strategies, relating them with the possible consequences generated in brand equity. Next, the method section describes the experimental research conducted. Then, the result, discussion, and final remarks section concludes the article. 


\section{BRAND IDENTITY STRATEGIES: FOREIGNNESS AND COUNTRY OF ORIGIN}

The language of a people is the result of its history, contacts, and coexistence with various countries. Two phenomena arise as a consequence of this process of linguistic formation: foreignness and lending (MAGNANI, 2014). Lending (HOUAISS, 2009) is the incorporation into the lexicon of a language of a term belonging to another language (e.g. marketing). As for foreignness, this is a method of composing words and a means of lexical renewal (BECHARA, 2012). It can present itself as an original term from the foreign language (e.g. "show") or one adapted to Portuguese (e.g. futebol/football).

The insertion of these words into our vocabulary generates discussions, especially among grammarians who believe that Portuguese is losing its originality and the particularities of the regional culture (STAUB, 1983). For those who are more nationalist, foreign words should only be used when there is no equivalent term in the Portuguese language and when their "portuguesification" is not viable. However, the population apparently holds a different position, since the adoption of foreign expressions, especially of English origin, is more recurrent than the portuguesification of words or the use of equivalent Brazilian terms.

Carvalho (1989) states that "made in USA" elements have been assimilated into the day-to-day of Brazilians. For example, by using the terms "leasing", "royalty", and "business", Brazilian citizens appear to acquire political and economic power. This admiration is becoming more and more strengthened (SOUZA et al., 2015) and can be seen in cinema, fashion, and television, generating the indiscriminate use of English terms, which ultimately causes graphic anarchy in the Portuguese language.

Media processes and advertising stimulate this practice and abuse the substitution of words from the Portuguese language by foreignisms (ARAÚJO; BALSALOBRE; BARBOSAPAIVA, 2015). Similarly, there are entrepreneurs who seek expressiveness in the English language to name their establishments. Paiva et al. (2002) conducted a study in order to verify what the motivators were in selecting terms in English to name establishments. They identified the four most cited reasons: i) beauty and refinement; ii) notoriety; iii) the positivity of the term; and iv) solely due to it being from the English language.

The naming strategy is relevant at the time a company establishes itself in the market (KOHLI; SURI, 2000). Consumers are attracted/discouraged by brand names loaded with meanings. From a branding strategy perspective (HILLENBRAND et al., 2013), the convenience of a brand name can be evaluated in two dimensions: (1) the inherent ease with which the name can be codified, retained, and retrieved from the memory and (2) the extent to which the name supports or reinforces the strategic positioning of the product/ service or company (PARK; JAWORSKI; MACLNNIS, 1986).

Foreignness appears to be geared mainly towards influencing the brand image indicator of the brand equity construct (KLINK; WU, 2014). While names of foreign brands may be relatively unknown, difficult to pronounce, and perhaps less memorable than names derived from the national language, they can, however, contain positive associations that affect the way consumers perceive and evaluate products (LECLERC; SCHMITT; DUBE, 1994).

Studies of Brazilian business owners have suggested that businesspeople, even without technical marketing knowledge, recognize the need to differentiate their business or product using a differentiated name (MAGNANI, 2014; PRADO, 2015). Some of these entrepreneurs turn to English to give a sophisticated appearance to their commercial name.

The study by Prado (2015) investigated the names of 7,271 establishments registered in a large Brazilian state. Of these, $11.8 \%$ had some element of the English language in their 
name. In turn, the study by Magnani (2014) demonstrated a significant result for the presence of foreignness in business. It showed that $41.1 \%$ of the 180 stores studied in prestigious locations in a Brazilian city had names with English foreignness and of the 280 stores in mass market locations, $55.2 \%$ did. Of the reasons claimed by some of these entrepreneurs regarding the choice of the foreign term to name the commercial establishment, $52 \%$ of the interviewees attributed the name to being a marketing strategy to attract more clients. Of the 100 business owners interviewed, $39 \%$ answered that this is a way to attract attention to the products sold, since a foreign name gives the status of quality product.

The studies shown confirmed the relevant presence of terms in English in the names of Brazilian stores and commercial establishments, but there is no research clarifying whether consumers really perceive a brand with foreignness as having more value than another without foreignness. In addition, no study presents an experimental format using a control group that is able to demonstrate whether the effect of foreignness is real or whether it is random. However, the study by Topolinski, Zürn, and Schneider (2015) has already suggested that there are relationships between brand name and paying higher prices and generating motivations to buy.

Complementary to the foreign naming of the brand strategy, the "country of origin" factor has become part of the repertoire of extrinsic indications of product evaluations by the consumer, along with price, brand name, and packaging (VERLEGH; STEENKAMP, 1999). Studies prove that consumers use information about the country of origin as an indicator of quality; that is, the "made in" label influences buying behavior, whether from the viewpoint of an animosity, motivations, or cultural dimensions effect (KOTLER et al., 2006; AICHNER, 2014).

The image of the country of origin is a derivative of the stereotypes that lead consumers to judge products in accordance with their geographical origin (DINNIE, 2015). Adverts divulged in mass media help to spread these stereotypes of the country of origin of brands. However, depending on the tradition of the country of origin in the production of the product, this stereotype can be perceived as being something positive or negative (YASIN; NOOR; MOHAMAD, 2007). Some consumers may assimilate the country of origin (e.g. made in USA) of a brand as being "gringo" and classify it as a "US invasion", thus attributing a negative character. This perception can occur due to both the brand being symbolic of the country of origin and it making clear where its origin is in its advertising messages.

On the other hand, correspondence of the country of origin of the brand with the country where the consumer resides or the nation he/she belongs to may generate a feeling of nationalism or pride (AICHNER, 2014). This consumer may thus attribute a positive evaluation to a brand that signals that it belongs to his/her native country. Therefore, the image of the country of origin can alter how much foreignness alters consumers' perceptions regarding brands. Lee, Chen, and Guy (2014) and Yasin et al. (2007) have already demonstrated that the image of the country of origin has consequences for brand equity indicators. However, consumer-based brand equity is multidimensional and depending on what is analyzed this effect may or may not be revealed.

\subsection{CONSEQUENCE GENERATED IN THE COMPOSITION OF CONSUMER-BASED BRAND EQUITY}

Company managers consider branding as a priority managerial activity due to the increasing understanding that brands are one of the most valuable intangible assets that companies possess (KELLER; LEHMANN, 2006; KELLER, 2016). According to Oliveira and Luce (2011), the term brand equity, or brand value, has spread into multiple meanings (WOOD, 2000). The different defining approaches of the construct derive from two 
BBR

15,6

610

distinct perspectives, one being based on the perception of the consumer and the other based on the company, especially on its financial dimension (CHRISTODOULIDES; DE CHERNATONY, 2010).

Consumer-based brand equity is multidimensional and involves consumers' attitudinal reactions regarding how much a brand is worth to them (KELLER, 2016). It is also termed strength of the brand or size of the brand (FELDWICK, 1996) or symbolic benefits of the brand for the consumer (OLIVEIRA-CASTRO et al., 2008). Its measurement signals the economic/social benefits that are gained if the brand is obtained or used (PORTO, 2018). A brand that presents positive brand equity obtains more favorable responses from customers than a version of the product or service with no name (KELLER; MACHADO, 2006).

Taking the various studies into account, Yoo, Donthu, and Lee (2000) and Yoo and Donthu (2001) recognize that brand loyalty, perceived quality, brand recognition, and positive associations with the brand are the most common dimensions of brand equity. However, other authors have proposed that there are some other complementary dimensions - exclusivity (KELLER, 1993; PORTO, 2018) and willingness to pay a premium price (NETEMEYER et al., 2004; PORTO, 2018) - that are empirically proven in the same measurement model (PORTO, 2018).

The first point that characterizes brand knowledge is brand awareness, that is, the ability to identify the brand (KELLER, 1993; KELLER; MACHADO, 2006). This ability involves two elements: recognition of the brand (consumers can correctly describe the brand) and memory of the brand, which requires consumers to retain the brand in their memory. Brand image is defined as "a set of associations related to the brand that consumers retain in their memory" (KELLER, 1993, p. 2). This may have a positive or negative value (PORTO, 2018).

With regard to brand loyalty, Oliver (1999) claims that this concerns a profound behavior of consistently buying and using a product again in the future, causing repeated purchases of the same brand or group of brands, even with the existence of external influences and marketing efforts that incentivize a change in behavior. It is a characteristic of the greatest value brands (AAKER, 2011) - consumers who are more loyal to brands attribute a higher value to them.

Perceived quality is defined as the understanding of the customer regarding the quality or superiority of a product or service in relation to the alternatives present in the market (ZEITHAML, 1988). It also forms part of the traditional dimensions of brand equity (KELLER, 2016). In the thinking of the authors Keller and Machado (2006), it is important that some associations with the brand are not only favorable, but also exclusive. Brand exclusivity (KELLER, 1993) involves distinct associations that are not shared with competitor brands.

Thus, in this study, we choose to measure the effect of two brand identity strategies, foreignness and country of origin, on brand equity using six indicators derived from the contributions of various authors, these being: brand knowledge, associated image, exclusivity, perceived quality, loyalty, and willingness to pay a premium price, as illustrated in Figure 1. In addition, the aim is to test whether there is a direct or moderated relationship between the country of origin message and foreignness in the brand equity indicators.

It is worth noting that the study uses control variables (covariates, not shown in the model), such as the socio-demographic variables (family income and respondent's age), as well as the frequency of purchase of the product. These factors appear to exert an influence on the measures of brand equity (LAOVIWAT; SUPPAPANYA; YOUSAPRONPAIBOON, 2014); however, they are not the focus of this study. 


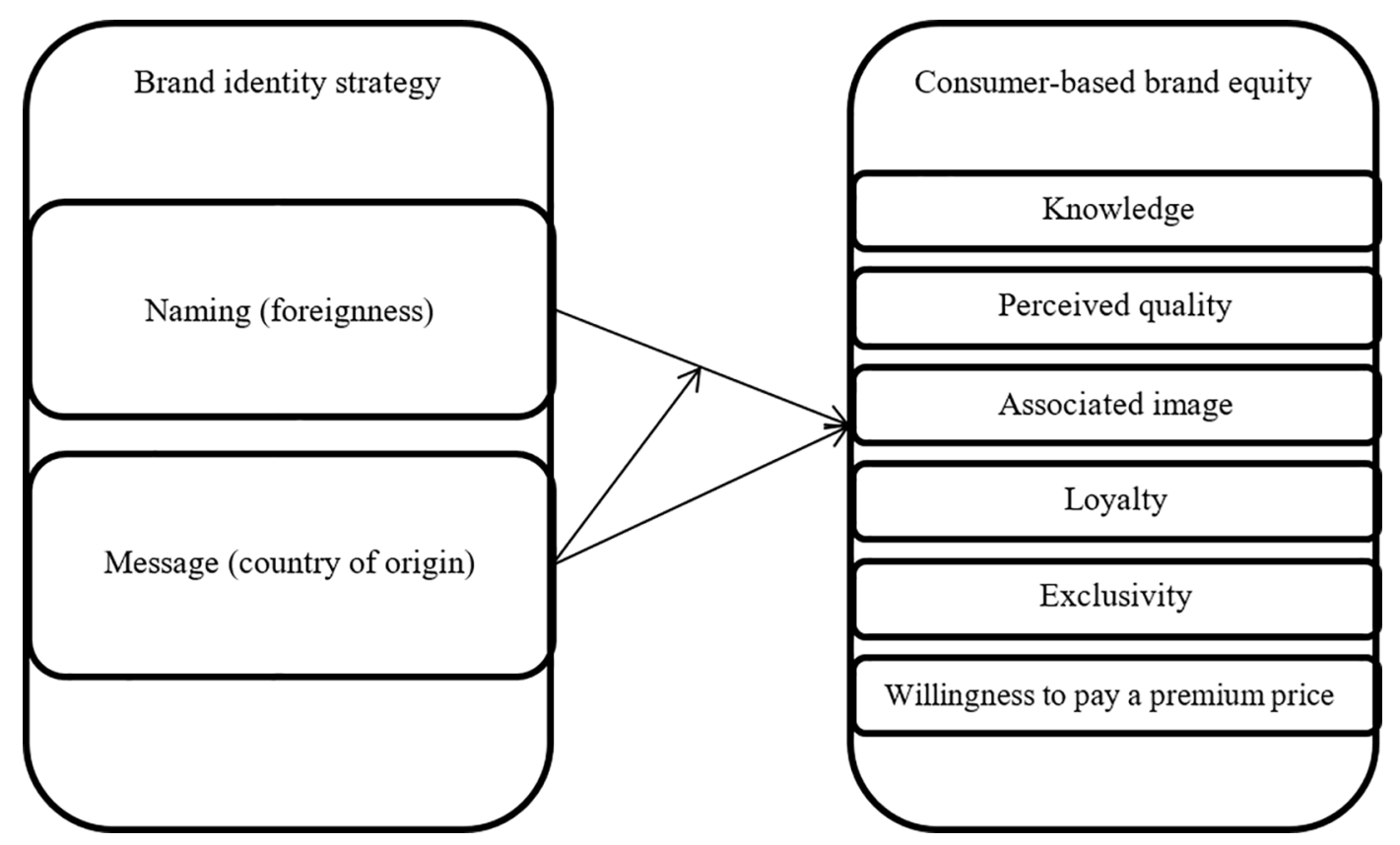

Figure 1. Research design.

\section{METHOD}

We test the model in Figure 1 by means of an experimental study (COZBY, 2006) with a $2 \times 2$ between-subjects design. The experimental method is a conclusive study that uses the manipulation of independent variables (intervention) to discover the effect of another variable called dependent, and contains a random sample in the distribution of participants, with the existence of a control group being possible. In this experimental study, we elaborate fictitious brands and fictitious adverts to make the experimental manipulation viable. We keep the layout of the advert (specifically created for the purpose of this study) constant and we manipulate the name of the brand in its English or Portuguese forms (foreignness independent variable) and the country of origin message (country of origin independent and moderating variable) to discover their effects on the brand equity indicators (dependent variable).

Our study uses three experimental groups and one control group. The four groups formed were shown the adverts, which were differentiated with regard to the language of the brand name (Portuguese - Br vs. English - USA) and the presence or not of the country of origin message. In each one of them, we evaluate the brand equity (and each one of its six indicators). The research design can be visualized in Chart 1.

Chart 1. Research design.

\begin{tabular}{|lcc|}
\hline Brand identity strategy & Without country of origin message & With country of origin message \\
\hline $\begin{array}{l}\text { Absence of foreignness (brand } \\
\text { in Portuguese) }\end{array}$ & Brand equity & Brand equity \\
$\begin{array}{l}\text { Presence of foreignness (brand } \\
\text { in English) }\end{array}$ & Brand equity & Brand equity \\
\hline
\end{tabular}


BBR

15,6

612

The experiment used a sample of 280 participants, where experimental group 1 had 68 answers, experimental group 2 had 66 answers, experimental group 3 had 67 answers, and the control group had 79 answers. We perform the random distribution of the participants into the groups via an electronic sorting mechanism (electronic questionnaire). Each person that accessed the link was randomly directed to a group that contained distinct manipulations of the independent variables. The sampling power calculation to make the experiment viable with the covariance analysis test with a mean-sized effect $(f=0.25)$ was in the order of $81.98 \%$, in order to minimize the Type 2 Error, or false negative. The socio-demographic profile of the sample is constituted by women representing $69.3 \%$ of the sample, with $66.6 \%$ of the respondents having an income of up to $8,433.00 \mathrm{BRL}$ and average age (M) equal to 25.3, with a standard deviation (S.D.) of 7.6.

We chose Jeans clothing as it is highly consumed in the Brazilian context, which facilitates proximity to the participants' consumption reality. It equally enables the elimination of problems of lack of familiarity with the product, which could distort the results of the study. Only $2.4 \%$ of the sample does not buy jeans in a period greater than once a year.

To avoid the participants already having any pre-established familiarity with brands and adverts already existing in the market, original brands (brand name that does not exist in its Portuguese and English version) and an original advert (keeping the layout and images the same, but altering the brand name and also the presence or absence of the country of origin message) were elaborated. Both were elaborated by an advertising professional.

We can see the final format of the adverts and the brands in Figure 2. The name of the brand chosen was Audácia and its English counterpart Audacity. In a previous phase to the experiment, four judges evaluated the name of this pair of brand names and of other created brands (doctors in consumer behavior). In addition, they judged the layout, country of origin message, and other attributes of the created adverts. The following alterations were carried out: location of the value-enhancing message within the advert; adjustments to the format of the advert for social media, simulating a post in the Instagram network, the most widely-used for photos in Brazil; care with the translations of the terms; and adaptations to the brand name so that it appeared with a credible name to be adopted by a brand of jeans.

The composition of the advert was carried out so that the photo chosen presented the product without distinction of sex, hence the image of the couple. With regard to the brand name variable, the one that most represented a brand of jeans and that had an English translation similar to the word in Portuguese was chosen, thus seeking a better comparison. The second variable explored was the country of origin message, which gave value to the origin being either Brazilian or North American.

The first advert is composed of the brand in Portuguese "Audácia" without any description, and the second contains the same brand together with the message "Jeans genuinamente brasileiro" ("Genuine Brazilian jeans"), highlighting the domestic origin of the product. In the third advert, the brand in English "Audacity" is found without any description and, finally, the last advert shows the same brand in English with the description "Genuine American jeans", conveying the United States origin. It is worth noting that the message chosen sought to value and attract the respondent's attention to the country of origin of the brand. A faithful translation of the message into English was also sought.

We also made efforts to simulate the layout of an advert and the context of advertising in a recognized social network, with the creation of a fictitious electronic address, in order to make the launch of the brand more realistic. 
audaciajeansoficial

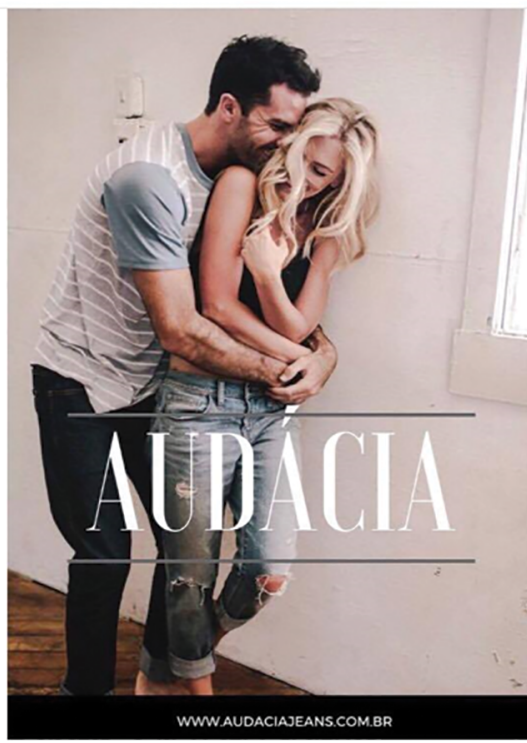

$\bigcirc \bigcirc \nabla$

HÁ 2 SEGUNDOS

audacityjeansofficial

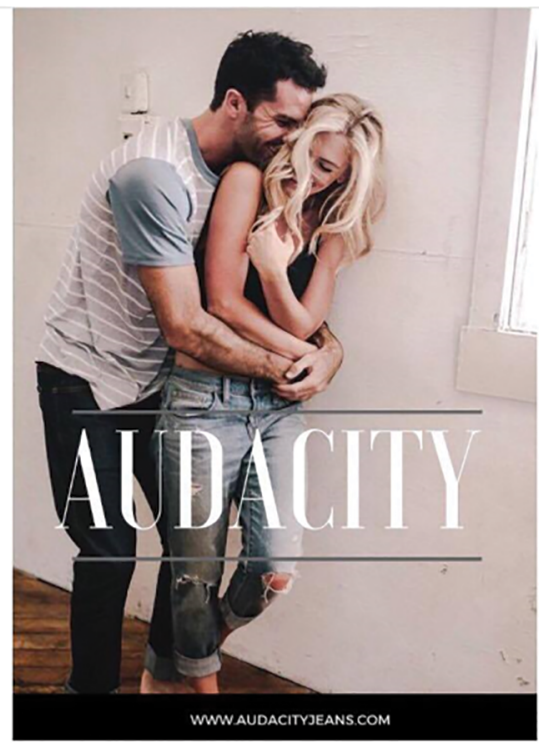

$\bigcirc \bigcirc \nabla$

HÁ 2 SEGUNDOS

Figure 2. Adverts and brands created for the data collection.

The collection of data for the experiment took place via the virtual platform Google Forms. To randomize the respondents into the groups, we used a randomization option of the tool. The question used to direct the participants into the groups was the respondents' date of birth. The allocation into the four groups occurred with the grouping of these allocated dates every 91 days. Each interval of dates led the participant to a different group. 
BBR

15,6

614

In Screen 1, we clarify regarding the purpose of the survey, answering time, agreement to participate, as well as a contact email for participants who sought to obtain more information. Screen 2 asked for the frequency of purchasing jeans clothing to be completed, with the aim of knowing the respondent's familiarity with the product. In Screen 3, the respondent had to communicate his/her date of birth, which would direct the person to a group. Screen 4 contained an introductory text reporting the intention to launch a new brand in the Brazilian market and then the advert was displayed. Below the image of the advert, the questions referring to the brand equity indicators validated by Porto (2018) were presented, namely: (1) brand knowledge, (2) perceived quality, (3) associated image, (4) exclusivity, (5) loyalty, and (6) willingness to pay a premium price. Screen 4 asked for the socio-demographic profile (gender, age, and income) to be completed and, finally, there was a thank you for participating.

It is worth noting that the questions related to the brand equity indicators needed to undergo adaptations. The advert portrayed a fictitious brand, so it would be the respondents' first contact and they would consequently have no previous knowledge. Thus, we adjusted and wrote the questions as follows: (1) In accordance with the advert, how well-known does the Audacity brand appear to be? (2) In accordance with the advert, what degree of quality does the Audacity brand appear to have? (3) In accordance with the advert, what image does the Audacity brand appear to have? (4) In accordance with the advert, how would you evaluate the exclusivity that Audacity appears to generate for people who buy this brand of jeans? (5) In accordance with the advert, how often do you think people would buy this brand over a year? (6) Based on this advert, what appears to be the highest price that people would pay for this brand of jeans? We maintained the 5-point scales from the instrument by Porto (2018), except for the price premium, which has a free numeric scale.

To revalidate the brand equity instrument, we conducted the Confirmatory Factor Analysis to test whether the six adapted indicators of brand equity are in fact grouped in the Brand Equity construct, as Figure 3 illustrates. The confirmatory factor analysis model presented very good indicators $(\mathrm{SMRS}=0.03, \mathrm{GFI}=0.99, \mathrm{AGFI}=0.98, \mathrm{CFI}=0.99$, and RMSEA $=$ 0.03 ). This model corroborates the factor validation already carried out by Porto (2018) and indicates that we can use the first order factor Brand Equity for the analysis purposes of this study, despite its wording having been adapted for fictitious brands. There is convergent validity $(\mathrm{C} . \mathrm{C}=0.87)$ and an acceptable average variance extracted $(\mathrm{AVE}=0.53)$.

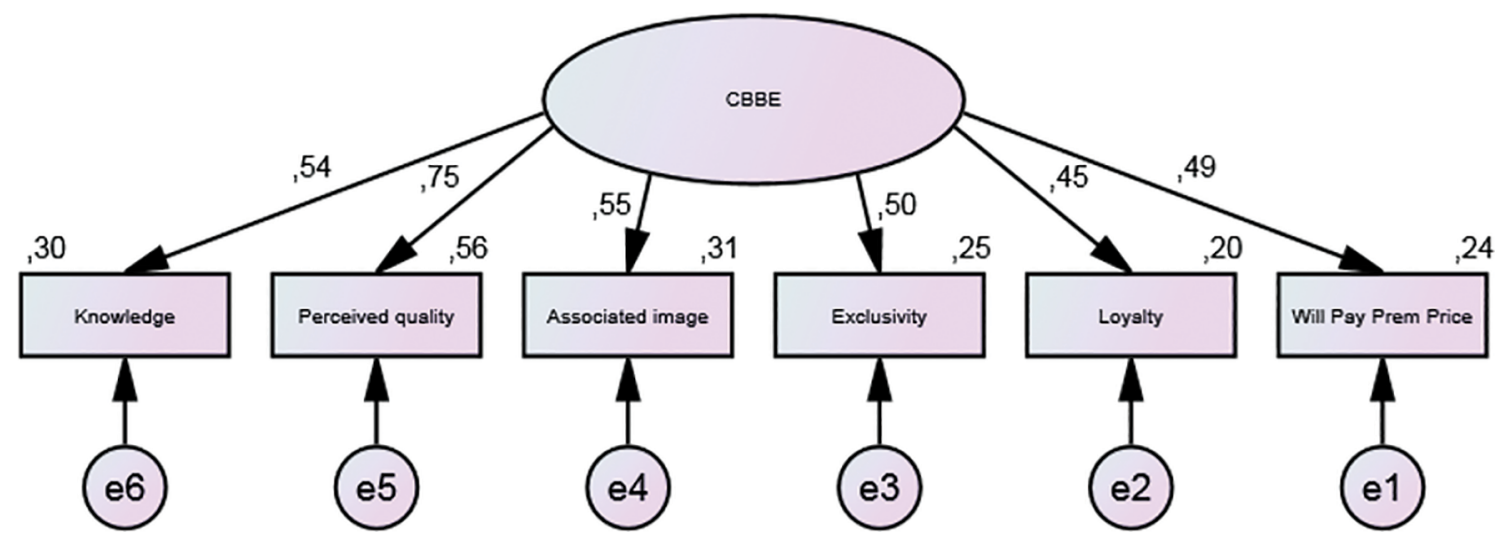

Figure 3. Standardized estimates and explained variance of the confirmatory factor model. Source: Data from the research. 
In Table 1, we can verify the descriptive analysis of the dependent variables. We can observe that all the indicators presented a low value. This is expected since the brands are fictitious and non-existent in the market. Of the scale indicators, associated image presented the highest mean, and degree of knowledge presented the greatest standard deviation. As willingness to pay a premium price has a free quantitative answer format, all the variables had to be standardized. Thus, values equal to 0 represent the mean, and positive (negative) values are with standard deviations above (below) the mean.

Table 1. Descriptive analysis of the brand equity indicators.

\begin{tabular}{lcccc}
\hline Variables & Scale & Mean & Standard Deviation & Factor loading \\
\hline Knowledge & 0 to 4 & 1.71 & 1.06 & 0.54 \\
Perceived quality & 0 to 4 & 2.48 & 0.72 & 0.75 \\
Associated image & 0 to 4 & 2.91 & 0.61 & 0.55 \\
Exclusivity & 0 to 4 & 1.81 & 0.86 & 0.50 \\
Loyalty & 0 to 4 & 1.93 & 0.90 & 0.45 \\
Willingness to pay a premium price & - & 202.54 & 108.11 & 0.49 \\
\hline
\end{tabular}

Source: Data from the research.

We conducted two analyses in the experiment. The covariance analysis was the first, measuring the effect that foreignness in the brand name (independent variable 1) and the country of origin message (independent variable 2) exercise over the general consumer-based brand equity construct (dependent variable), and having the socio-demographic variables (age, family income, and gender) and frequency of purchase as a control variable. The second analysis concerns a multiple covariance analysis with the same independent and control variables, but with the six brand equity indicators as dependent variables.

\section{RESULTS}

Initially, we show the results for the experiment involving the effects of the independent variables on the general brand equity construct (Model 1), and then for the effects on the six brand equity indicators (Model 2).

Model 1 (Table 2) presented an $\mathrm{R}^{2}$ of $6 \%$ as a general model that provides little explanation for the general brand equity construct. However, the focus is not on identifying the best predictors of the brand equity indicator, but rather, to observe whether the variables tested exert any explanatory power over the dependent variable.

As shown in Table 2, the effect of the independent variable foreignness in the brand name on the dependent variable brand equity (general construct), after the control variables, presented a significant relationship $[F(1,272)=4.06, p \leq 0.05$; eta squared $=1 \%]$. As for the country of origin message, this did not present a direct or moderating effect on the general brand equity construct $(\mathrm{p}>0.05)$. The control variable respondent's age appears to have a significant relationship $[\mathrm{F}(1,272)=8.79, \mathrm{p} \leq 0.01$; eta squared $=3 \%]$, indicating that the higher the age, the lower the brand equity $(\mathrm{B}=-0.02$; standard error $=0.01)$. 
BBR

15,6

616

Table 2. Effectiveness of foreignness, the country of origin message, and control variables over the general brand equity construct.

\begin{tabular}{lccc}
\hline \multicolumn{4}{c}{ Model 1: Dependent variable $=$ general brand equity construct } \\
\hline Variables & $\mathrm{F}$ & Sig. & Partial eta squared \\
\hline Intercept & 1.28 & 0.25 & 0.00 \\
Age & 8.79 & 0.01 & 0.03 \\
Foreignness & 4.06 & 0.04 & 0.01 \\
Frequency of purchase & 2.01 & 0.15 & 0.00 \\
Sex & 0.40 & 0.52 & 0.00 \\
Income & 0.16 & 0.68 & 0.00 \\
Country of origin message & 0.15 & 0.90 & 0.00 \\
Foreignness * Country of origin message & 0.09 & 0.76 & 0.00 \\
\hline
\end{tabular}

Source: Data from the research.

Figure 4 illustrates the effect of foreignness on the general brand equity construct. We do not show the country of origin message as it did not present a significant relationship. The brand in its foreign version in English - United States of America - presented a mean equal to 0.14 and standard error equal to 0.11 and in the Brazilian version it presented a mean of -0.11 and standard error equal to 0.12 . This denotes that when foreignness is used in the brand name the respondent's perception of value is greater.



Figure 4. Effect of foreignness on the general brand equity indicator. Source: Data from the research.

The multiple covariance analysis in Model 2 - Table 3 (for each brand equity indicator) - also presented low $\mathrm{R}^{2}$, of between $2 \%$ and $11 \%$. However, again the interest was not in finding the main predictors of each brand equity indicator, but rather, to observe whether the manipulations carried out exerted any influence, however weak these may be.

Regarding the independent variable foreignness, we only observed a significant relationship with the indicators for associated image $[\mathrm{F}(1,272)=4.12, \mathrm{p} \leq 0.05$; eta squared $=2 \%]$ and willingness to pay a premium price $[\mathrm{F}(1,272)=7.18, \mathrm{p} \leq 0.01$; eta squared $=3 \%$ ]. We show both effects in Figure 5. In Graph B we perceive that the brand with the presence of foreignness (in English) generates a more positive image ( $m e a n=0.16$; 
Table 3. Effectiveness of foreignness, country of origin message, and control variables over brand equity indicators.

\begin{tabular}{|c|c|c|c|c|}
\hline \multicolumn{2}{|c|}{ Model 2: dependent variables - 6 brand equity indicators } & $\mathrm{F}$ & Sig. & Partial eta squared \\
\hline \multirow{6}{*}{ Intercept } & Knowledge & 1.06 & 0.30 & 0.01 \\
\hline & Perceived quality & 4.71 & 0.03 & 0.02 \\
\hline & Associated image & 4.62 & 0.03 & 0.02 \\
\hline & Exclusivity & 0.30 & 0.58 & 0.00 \\
\hline & Loyalty & 0.13 & 0.71 & 0.00 \\
\hline & Willingness to pay a premium price & 0.24 & 0.62 & 0.00 \\
\hline \multirow{6}{*}{ Frequency of purchase } & Knowledge & 0.08 & 0.77 & 0.00 \\
\hline & Perceived quality & 0.05 & 0.82 & 0.00 \\
\hline & Associated image & 0.23 & 0.63 & 0.00 \\
\hline & Exclusivity & 1.21 & 0.27 & 0.00 \\
\hline & Loyalty & 24.45 & 0.00 & 0.08 \\
\hline & Willingness to pay a premium price & 0.45 & 0.50 & 0.00 \\
\hline \multirow{6}{*}{ Age } & Knowledge & 3.55 & 0.06 & 0.01 \\
\hline & Perceived quality & 12.00 & 0.00 & 0.04 \\
\hline & Associated image & 11.25 & 0.00 & 0.04 \\
\hline & Exclusivity & 0.05 & 0.81 & 0.00 \\
\hline & Loyalty & 3.03 & 0.08 & 0.01 \\
\hline & Willingness to pay a premium price & 1.00 & 0.32 & 0.00 \\
\hline \multirow{6}{*}{$\begin{array}{l}\text { Monthly household } \\
\text { income }\end{array}$} & Knowledge & 0.01 & 0.91 & 0.00 \\
\hline & Perceived quality & 0.03 & 0.86 & 0.00 \\
\hline & Associated image & 0.40 & 0.53 & 0.00 \\
\hline & Exclusivity & 0.66 & 0.42 & 0.00 \\
\hline & Loyalty & 0.23 & 0.63 & 0.00 \\
\hline & Willingness to pay a premium price & 4.98 & 0.03 & 0.02 \\
\hline \multirow{6}{*}{ Foreignness } & Knowledge & 1.53 & 0.22 & 0.01 \\
\hline & Perceived quality & 2.38 & 0.12 & 0.09 \\
\hline & Associated image & 4.12 & 0.04 & 0.02 \\
\hline & Exclusivity & 0.00 & 0.96 & 0.00 \\
\hline & Loyalty & 0.00 & 0.93 & 0.00 \\
\hline & Willingness to pay a premium price & 7.84 & 0.01 & 0.03 \\
\hline \multirow{6}{*}{$\begin{array}{l}\text { Country of origin } \\
\text { message }\end{array}$} & Knowledge & 2.21 & 0.14 & 0.01 \\
\hline & Perceived quality & 0.10 & 0.75 & 0.00 \\
\hline & Associated image & 2.75 & 0.10 & 0.01 \\
\hline & Exclusivity & 0.26 & 0.61 & 0.00 \\
\hline & Loyalty & 2.66 & 0.10 & 0.01 \\
\hline & Willingness to pay a premium price & 0.90 & 0.34 & 0.00 \\
\hline \multirow{6}{*}{$\begin{array}{l}\text { Foreignness * country } \\
\text { of origin message }\end{array}$} & Knowledge & 0.00 & 0.98 & 0.00 \\
\hline & Perceived quality & 1.61 & 0.21 & 0.01 \\
\hline & Associated image & 0.53 & 0.47 & 0.00 \\
\hline & Exclusivity & 3.83 & 0.05 & 0.01 \\
\hline & Loyalty & 2.36 & 0.13 & 0.01 \\
\hline & Willingness to pay a premium price & 1.19 & 0.28 & 0.00 \\
\hline
\end{tabular}


standard error $=0.1$ ) in the eyes of the consumers than the Brazilian brand (mean $=-0.07$; standard error $=0.1)$. In Graph $\mathrm{C}$ we find that the brand with the name in English also generates a greater willingness among the consumers to pay a premium price (mean = 0.18 ; standard error $=0.1$ ) than the brand without foreignness (mean $=-0.16$; standard error $=0.1$ ).
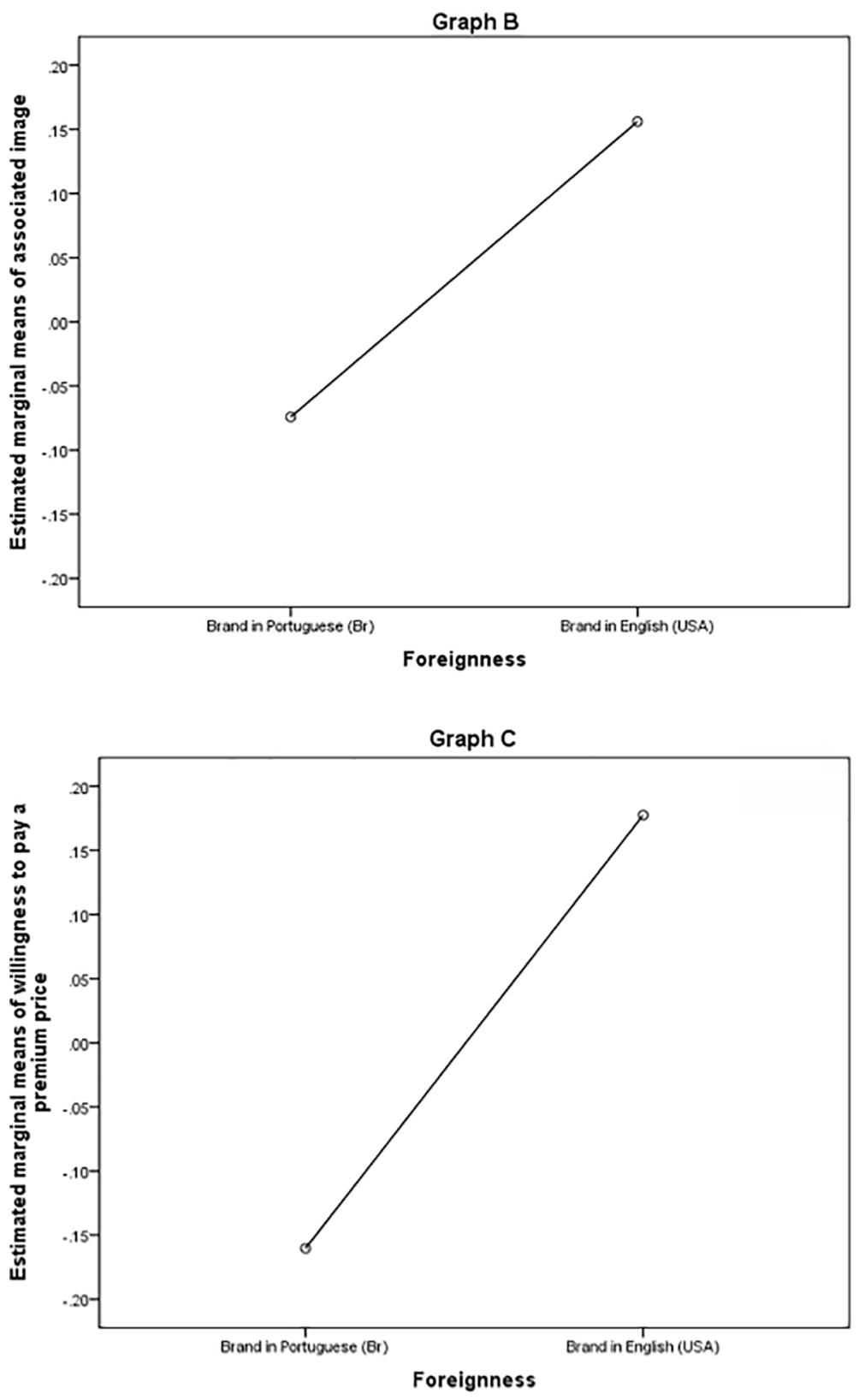

Figure 5. Effect of foreignness on the positive association with the brand image shown in Graph B and on the willingness to pay a premium price in Graph C.

Source: Data from the research. 
The country of origin message did not present a direct effect for any brand equity indicator, but it presented itself as moderating in the relationship between foreignness and the exclusivity indicator $[\mathrm{F}(1,272)=3.83, \mathrm{p} \leq 0.05$; eta squared $=1 \%]$. Graph D (Figure 6) illustrates this relationship. The relationship indicates that there is greater exclusivity for the consumers with the brand in Portuguese $(\mathrm{Br})$ together with the message valuing the domestic origin of the product (mean $=0.17$; standard error $=0.1$ ) and when the brand is in English (USA) without the message valuing the foreign country of origin (mean = 0.11 ; standard error $=0.1$ ). Exclusivity is lower when the brand without foreignness does not present the country of origin message (mean $=-0.13$; standard error $=0.1$ ) and when the brand with foreignness presents the country of origin message (mean $=-0.07$; standard error $=0.1$ ).

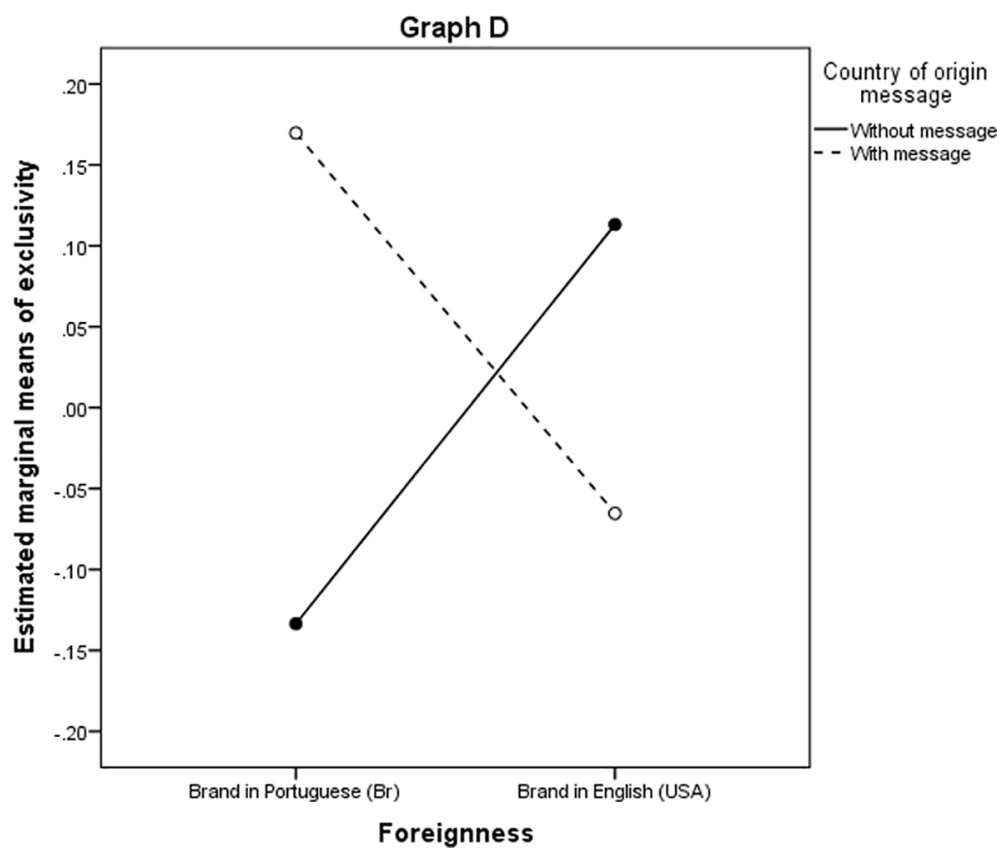

Figure 6. Effect of foreignness, moderated by the country of origin message, over the exclusivity of the brand.

Source: Data from the research.

It stands out that some control variables exert an effect over the brand equity indicators. The frequency of purchase of the product throughout the year indicated a positive influence with consumer loyalty to the brand $(\mathrm{B}=0.4 ; \mathrm{p} \leq 0.01)$. Age assumed a negative influence with the two indicators, revealing that the higher the age, the lower the perceived quality $(\mathrm{B}$ $=-0.25 ; \mathrm{p} \leq 0.01)$ and the more negative the image associated with the brand $(\mathrm{B}=-0.25 ; \mathrm{p}$ $\leq 0.01)$. Finally, income positively influenced the willingness to pay a premium price: the higher the income, the greater the willingness to pay a premium price $(B=0.06 ; p \leq 0.05)$. 
BBR

15,6

620

\section{DISCUSSION}

In general terms, the results showed that a foreignness and country of origin brand identity strategy helps to build the equity of a recently-created, fictitious brand (HILLENBRAND et al., 2013; LEE et al., 2014; TOPOLINSKI et al., 2015; KELLER, 2016; SCHMELTZ; KJELDSEN, 2016). Foreignness exerted a positive and direct effect over the consumerbased brand equity, especially on the indicators for associated image and willingness to pay a premium price, and the country of origin exerted a moderating effect on the exclusivity of the brand. Thus, both brand identity strategies help to compose brand equity (KELLER, 2016), but in an interactive and partial way.

This study took an internal view of foreignness and country of origin; that is, from a Brazilian's viewpoint and from the perspective of what he/she perceives with regard to foreign brands. The Brazilian consumer reacts to English foreignness (USA) in a positive way, which is consistent with the brand naming strategy that Brazilian entrepreneurs typically adopt for their establishments (MAGNANI, 2014; PRADO, 2015). They believe, for example, that it is more chic and stylish if the brand they manage is named in English rather than its Portuguese counterpart, thus corroborating studies that found a relationship between foreignness and a more positive image (LECLERC et al., 1994; KLINK; WU, 2014). This is directly related to the image stereotype of countries, a phenomenon that has been studied extensively (YASIN et al. 2007; LEE et al., 2014). This study addresses one of its aspects, concerning the image of a North American (USA) product versus a Brazilian one in the eyes of Brazilians themselves.

But more than that, this is the first research to demonstrate a relationship between a foreignness and country of origin brand identity strategy and the result in brand equity using an experimental study. Both lines of research have followed different paths (KELLER \& LEHMANN, 2006; KELLER, 2016), but it would be natural to expect that branding strategy presented a relationship with brand equity, since the former is a strategy and the latter is a measure of result among consumers.

In addition, consumers are more likely to pay a premium price, possibly because the foreign language brand appears to be imported; therefore simulating having a higher cost and thus, being able to charge more (FERNANDES; ALVES, 2014). Foreignness did not have any relationship with greater knowledge, perceived quality, and brand loyalty. Therefore, significantly, it does not help the brand to be naturally more famous, nor does it signal greater quality or generate the motivation to buy more. This result demonstrates that its influence on brand equity is not generalized, but instead partial. That is, it helps in beginning to create brand equity, and is seen in some indicators. This would go against a previous study (LEE et al., 2014) that found generalized effects on brand equity. However, this study was an experimental one, with a control group and with a brand that was nonexistent in the market, in order to demonstrate a clearer effect, which makes the result more robust for such a test.

The country of origin message has no direct relationship with brand equity, which would go against previous studies (YASIN et al., 2007; LEE et al., 2014), but helps foreignness to exert an influence in building the exclusivity of the brand equity. The brand becomes more exclusive if it is domestic (Brazilian) with a country of origin message, signaling national pride (AICHNER, 2014), or if it is foreign without a United States country of origin message. In this latter case, it is not making clear whether a truly foreign brand is concerned. This possibly occurs because consumers do not like to see self-praising by a foreign country that is not their own.

The socio-demographic variables and frequency of purchase were influent, as expected (LAOVIWAT et al., 2014), but the results were complementary to what was already known with the traditional measures of brand equity. In this study, consumers with a higher income 
are in a better position to pay a higher price, young people tend to be less discerning regarding perceived quality and attribute a positive image to brands more easily, and high frequency of purchase in the category present a greater tendency for loyalty.

\section{CONCLUSION}

Some entrepreneurs have assigned names in English to their establishments. Some of them turn to brand identity strategies to link their products with positive characteristics of a foreign country. However, the effectiveness of this strategy, which is so important for starting a business, has not been tested in terms of brand equity. This study overcomes this limitation and demonstrates that foreignness and its interaction with country of origin have a direct influence over consumer-based brand equity. This study thus contributes with theories about the effectiveness of branding over brand equity measures. Few studies have empirically shown the relationship between both constructs.

As it is an experiment, with a control group, the results of the research contain good internal validity. The findings of the study enable some implications for the marketing of new ventures or new products or services, such as: a Brazilian brand with a name in English increases brand equity via the positive associated image and willingness to pay a premium price, and if not associated with literally belonging to a foreign country, it increases exclusivity. In turn, a Brazilian brand with a name in Portuguese only increases brand equity via exclusivity if it uses a domestic country of origin message.

Among the limitations of the study is the fact that it only tested the name in English of only one (created) brand. In addition, we place the country of origin message in a static advert and the test only considers one product. Therefore, care with generalizations should be considered. Future research could overcome these limitations by addressing more brands of different products, with other languages, and a different country of origin message other than originating from the United States of America.

The authors declare that they have no conflict of interest.

\section{REFERENCES}

AAKER, D. A. Marcas- brand equity: Gerenciando o valor da marca. Rio de Janeiro: Elsevier, 1998.

AAKER, D. A. Building strong brands. New York: Simon and Schuster, 2011.

AICHNER, T. Country-of-origin marketing: A list of typical strategies with examples. Journal of Brand Management, v. 21, n. 1, p. 81-93, 2014.

ARAÚJO, L. S. D.; BALSALOBRE, S. R. G.; BARBOSAPAIVA, C. L. O uso do inglês em contexto comercial no Brasil e em Portugal: Questões linguísticas e culturais. São Paulo: Cultura Acadêmica, 2015.

BECHARA, E. Moderna gramática portuguesa: Revista, ampliada e atualizada conforme o novo acordo ortográfico. Nova Fronteira, 2012.

BRODIE, R. J.; BENSON-REA, M. Country of origin branding: An integrative perspective. Journal of Product \& Brand Management, v. 25, n. 4, p. 322-336, 2016.

CARVALHO, N. Empréstimo lingüistico. São Paulo: Ática, 1989.

CHRISTODOULIDES, G.; DE CHERNATONY, L. Consumer-based brand equity conceptualization and measurement: A literature review. International Journal of Market Research, v. 52, n. 1, p. 43-66, 2010.

CORONEL, D. A.; DE AZEVEDO, A. F. Z.; CAMPOS, A. C. Política industrial e desenvolvimento econômico: A reatualização de um debate histórico. Brazilian Journal of Political Economy, v. 34, n. 1, p. 103-119, 2014.

COZBY, P.C. Métodos de pesquisa em ciências do comportamento. São Paulo: Atlas, 2006.

DINNIE, K. Nation branding: Concepts, issues, practice. New York: Routledge, 2015.

FELDWICK, P. Do we really need "brand equity"?. The Journal of Brand Management, v. 4, n. 1, p. 9-28, 1996.

FERNANDES, P. C. N. N.; ALVES, A. Variações cambiais e seu impacto na importação brasileira no período de 1999 a 2013. Revista Eletrônica de Debates em Economia, v. 3, n. 1, p. 1-92, 2014. 
BBR

15,6

GONÇALVES, R. Economia política internacional: Fundamentos teóricos e as relações internacionais do Brasil. Rio de Janeiro: Elsevier Brasil, 2017.

HILLENBRAND, P.; ALCAUTER, S.; CERVANTES, J.; BARRIOS, F. Better branding: brand names can influence consumer choice. Journal of Product \& Brand Management, v. 22, n. 4, p. 300-308, 2013.

HOUAISS, A. Dicionário Houaiss eletrônico. Rio de Janeiro: Instituto Antônio Houaiss e Editora Objetiva Ltda, 2009.

KELLER, K. L. Conceptualizing, measuring, and managing customer-based brand equity. Journal of Marketing, v. 57, n. 1, p. 1-22, 1993.

KELLER, K. L. Reflections on customer-based brand equity: perspectives, progress, and priorities. $A M S$ Review, v. 6, n. 1-2, p. 1-16, 2016.

KELLER, K. L.; LEHMANN, D. R Brand and branding: Research findings and future priorities. Marketing Science, v. 25, n. 6, p. 740-759, 2006.

KELLER, K. L.; MACHADO, M. Gestão estratégica de marcas. São Paulo: Pearson Prentice Hall, 2006.

KLINK, R. R.; WU, L. The role of position, type, and combination of sound symbolism imbeds in brand names. Marketing Letters, v. 25, n. 1, p. 13-24, 2014.

KOHLI, C.S.; SURI, R. Brand names that work: a study of the effectiveness of different types of brand names. Marketing Management Journal, v. 10, n. 2, p. 112-120, 2000.

KOTLER, P.; GERTNER, D.; REIN, I.; HAIDER, D. Marketing de lugares: Como conquistar crescimento de longo prazo na América Latina e no Caribe. São Paulo: Prentice Hall, 2006.

LAOVIWAT, P.; SUPPAPANYA, P.; YOUSAPRONPAIBOON, K. A study of demographics influencing on consumer behavior and attitude towards brand equity of optical business in Thailand. International Journal of Trade, Economics and Finance, v. 5, n. 4, p. 347-350, 2014.

LECLERC, F.; SCHMITT, B. H.; DUBÉ, L. Foreign branding and its effects on product perceptions and attitudes. Journal of Marketing Research, v. 31, n. 2, p. 263-270, 1994.

LEE, H. M., CHEN, T.; GUY, B. S. How the country-of-origin image and brand name redeployment strategies affect acquirers' brand equity after a merger and acquisition. Journal of Global Marketing, v. 27, n. 3, p. 191-206, 2014.

LEITE, R. C.; WINCK, C. A.; CARVALHO, D. M.; ZONIN, V. J. A Influência do estrangeirismo no processo de construção da marca no agronegócio. Brazilian Business Review, v. 9, n. 1, p. 110-133, 2012.

MAGNANI, C. S. O estrangeirismo como fator de prestígio social ou estratégia de marketing em estabelecimentos comerciais de Curitiba. Dissertação (Mestrado Interdisciplinar em Ciências Humanas), Universidade Tuiuti do Paraná, Curitiba, PR, Brasil, 2014.

MORAIS, C. M. L.; MARRA, V. A evolução da estrutura do comércio exterior. Idea, v. 2, n. 1, p. 65-78, 2011.

NETEMEYER, R.G.; KRISHNAN, B.; PULLIG, C.; WANG, G.; YAGCI, M.; DEAN, D.; RICKS, J.; WIRTH, F. Developing and validating measures of facets of customer-based brand equity. Journal of Business Research, v. 57, n. 2, p. 209-224, 2004.

OLIVEIRA, M. O. R. de; LUCE, F. B. O valor da marca: Conceitos, abordagens e estudos no Brasil. Revista Eletrônica de Administração, v. 17, n. 2, p. 502-529, 2011.

OLIVEIRA-CASTRO, J. M.; FOXALL, G. R.; JAMES, V. K.; POHL, R. H.; DIAS, M. B.; CHANG, S. W. Consumer-based brand equity and brand performance. The Service Industries Journal, v. 28, n. 4, p. 445461, 2008.

OLIVER, R. L. Whence consumer loyalty? Journal of Marketing, v. 63, n. 4, p. 33-44, 1999.

PAIVA, M. F.; PONTES, I.; MERCURIO, A. S.; MORAES, A. C.; TREVISOLI, J.; CAMARGO, L. P. O uso de estrangeirismo em nomes de estabelecimentos comerciais na cidade de Arapongas (PR). Signum, v. 5, n. 1, p. 227-237, 2002.

PARK, C. W.; JAWORSKI, B. J.; MACLNNIS, D. J. Strategic brand concept-image management. Journal of Marketing, v. 50, n. 4, p. 135-145, 1986.

PENNYCOOK, A. (2017). The cultural politics of English as an international language. New York: Taylor \& Francis, 2017.

PORTO, R. Consumer-based brand equity of products and services: Assessing a measurement model with competing brands. Brazilian Journal of Marketing, v. 17, n.2, p. 150-165, 2018.

PRADO, N. C. O uso do inglês em contexto comercial no Brasil e em Portugal: Questões linguísticas e culturais. São Paulo: Cultura Acadêmica, 2015.

SCHMELTZ, L.; KJELDSEN, A. K. Naming as strategic communication: Understanding corporate name change through an integrative framework encompassing branding, identity and institutional theory. International Journal of Strategic Communication, v. 10, n. 4, p. 309-331, 2016. 
SOUZA, S. M. DA F.; BORGES, C. G.; DA SILVA, J. G.; RABELO, P. B. Estrangeirismos: vestígios de poder da língua inglesa. Revista Eletrônica Saberes Múltiplos, v. 1, n. 2, p. 32-46, 2015.

STAUB, A. O empréstimo linguístico: Um estudo de caso. Porto Alegre: Acadêmica, 1983.

TOPOLINSKI, S.; ZÜRN, M.; SCHNEIDER, I. K. What's in and what's out in branding? A novel articulation effect for brand names. Frontiers in Psychology, v. 6, . 585, p. 1-10, 2015.

VERLEGH, P. W.; STEENKAMP, J. B. E. A review and meta-analysis of country-of-origin research. Journal of Economic Psychology, v. 20, n. 5, p. 521-546, 1999.

WOOD, L. Brands and brand equity: Definition and management. Management Decision, v. 38, n. 9, p. 662$669,2000$.

YASIN, N. M.; NOOR, M. N.; MOHAMAD, O. Does image of country-of-origin matter to brand equity? Journal of Product \& Brand Management, v. 16, n. 1, p. 38-48, 2007.

YOO, B.; DONTHU, N. Developing and validating multidimensional consumer-based brand equity scale. Journal of Business Research, v. 52, n. 1, p. 1-14, 2001.

YOO, B.; DONTHU, N.; LEE, S. An examination of selected marketing mix elements and brand equity. Journal of Academy of Marketing Science, v. 28, n. 2, p. 195-211, 2000.

ZEITHAML, V. A. Consumer perceptions of price, quality, and value: A means-end model and synthesis of evidence, Journal of Marketing, v. 52, n. 3, p. 2-22, 1988. 